\title{
Rethinking the Financial Design of the World Bank
}

\section{Devesh Kapur and Arjun Raychaudhuri}

\author{
Abstract
}

Since their inception, through 2012, the institutions comprising the World Bank group have been involved in lending nearly a trillion dollars. In this paper, we focus on the IBRD, which is the core of the World Bank. The IBRD has the potential to continue to grow and be an important player in official financial flows, supporting critical long-term development projects with large social returns, in sectors ranging from infrastructure, social sectors, or environment.

The paper argues that this is unlikely to occur in the absence of serious changes in the Bank's financial structure and lending practices. The relative slow pace of loan growth can be tied directly to difficult constraints both in terms of how the IBRD manages its leverage and equity increases the gearing ratio has stayed materially unchanged, and there have been only four equity raises since the inception of the World Bank - a period which has seen four global recessions.

This paper seeks to outline the internal and external constraints to capital and gearing, and examines why such constraints have arisen. Subsequently, the paper examines some options that could overcome these constraints.

JEL Codes: F3, G2

Keywords: World Bank, IBRD, finance 


\title{
Rethinking the Financial Design of the World Bank
}

\author{
Devesh Kapur \\ University of Pennsylvania \\ Arjun Raychaudhuri \\ IFMR Rural Channels and Services (IRCS)
}

We are grateful to Shweta Aggarwal and Pooja Khosla for excellent research assistance and to Todd Moss and Scott Morris for helpful comments and suggestions on an earlier draft..

Devesh Kapur and Arjun Raychaudhuri . 2014. "Rethinking the Financial Design of the World Bank." CGD Working Paper 352. Washington, DC: Center for Global Development.

http://www.cgdev.org/publication/rethinking-financial-design-world-bank-workingpaper-352

Center for Global Development 2055 L Street., NW Washington, DC 20036

202.416 .4000

(f) 202.416 .4050

www.cgdev.org
The Center for Global Development is an independent, nonprofit policy research organization dedicated to reducing global poverty and inequality and to making globalization work for the poor. Use and dissemination of this Working Paper is encouraged; however, reproduced copies may not be used for commercial purposes. Further usage is permitted under the terms of the Creative Commons License.

The views expressed in CGD Working Papers are those of the authors and should not be attributed to the board of directors or funders of the Center for Global Development. 


\section{Contents}

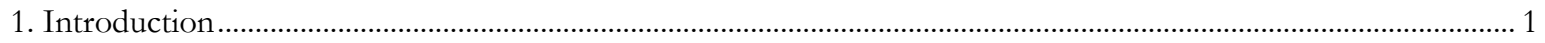

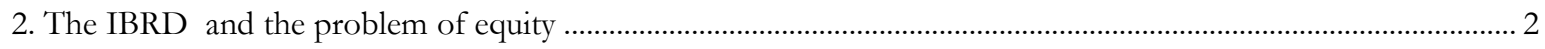

The political framework results in the low equity injections observed ................................................................. 3

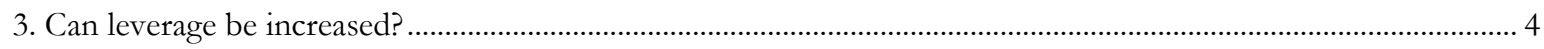

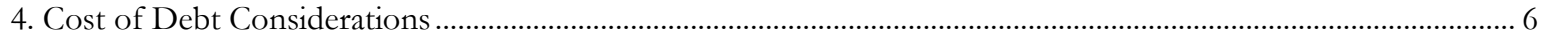

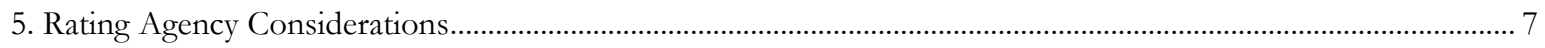

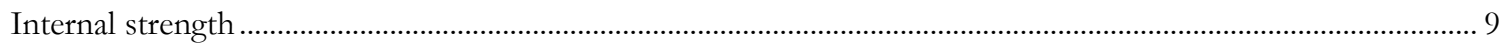

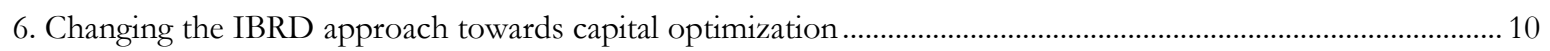

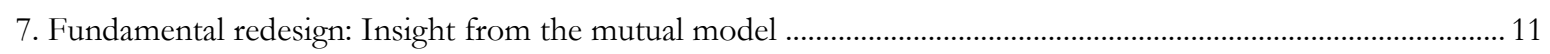

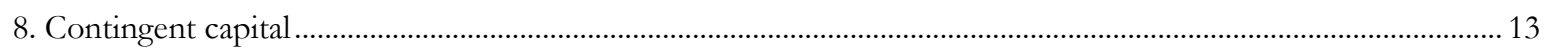

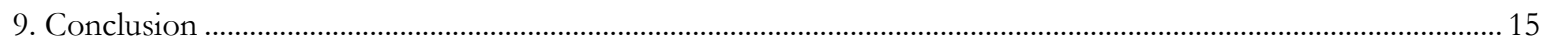

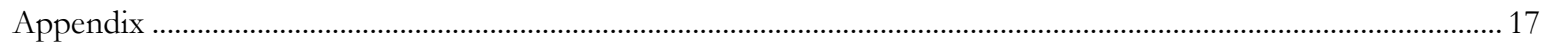

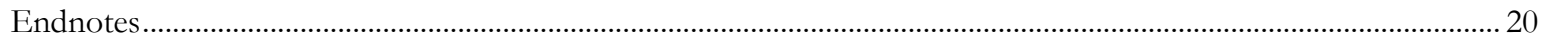





\section{Introduction}

The genesis of the World Bank lies in the creation of the International Bank for Reconstruction and Development (IBRD), following a conference at Bretton Woods in 1944 (which also led to the creation of the International Monetary Fund). Today the World Bank Group comprises in addition to the IBRD, the International Development Association (IDA), International Finance Corporation (IFC), Multilateral Investment Guarantee Agency (MIGA) and International Centre for Settlement of Investment Disputes (ICSID). Since their inception, through 2012, the institutions comprising the World Bank group have been involved in lending nearly a trillion dollars (Table 1).

Table 1. The World Bank Group Institutions

\begin{tabular}{|l|l|l|l|}
\hline & Established & $\begin{array}{l}\text { No. of Member } \\
\text { Countries }\end{array}$ & Operations \\
\hline $\begin{array}{l}\text { International Bank for } \\
\text { Reconstruction and } \\
\text { Development (IBRD) }\end{array}$ & 1944 & 186 & $\begin{array}{l}\text { Cumulative Lending: } \\
\$ 571 \text { billion }\end{array}$ \\
\hline $\begin{array}{l}\text { International Development } \\
\text { Association (IDA) }\end{array}$ & 1960 & 169 & $\begin{array}{l}\text { Cumulative Commitments: } \\
\$ 252 \text { billion }\end{array}$ \\
\hline $\begin{array}{l}\text { International Finance } \\
\text { Corporation (IFC) }\end{array}$ & 1956 & 182 & $\begin{array}{l}\text { Gross Commitments } \\
\text { Portfolio: } \$ 165 \text { billion }\end{array}$ \\
\hline $\begin{array}{l}\text { Multilateral Investment } \\
\text { Guarantee Agency (MIGA) }\end{array}$ & 1988 & 174 & $\begin{array}{l}\text { Cumulative Guarantees: } \\
\$ 27 \text { billion }\end{array}$ \\
\hline $\begin{array}{l}\text { International Center for } \\
\text { Settlement of Investment } \\
\text { Disputes (ICSID) }\end{array}$ & 1966 & 143 & $\begin{array}{l}\text { Total cases registered: } \\
292\end{array}$ \\
\hline
\end{tabular}

Source: Annual Reports, 2012

In this paper we focus on the IBRD, which is the core of the World Bank. Although IDA, the concessional arm of the World Bank, has been an important source of financial resources for poor countries, the combination of fiscal pressures in traditional donor countries and impending graduation of major borrowers means that it will very likely shrink over this decade. The IBRD, on the other hand, has the potential to continue to grow and be an important player in official financial flows, supporting critical long-term development projects with large social returns, in sectors ranging from infrastructure, social sectors or environment.

The paper argues that this is unlikely to occur in the absence of serious changes in the Bank's financial structure and lending practices. Between 1990 and 2008 the Bank's loans outstanding remained unchanged (at USD 99 billion) even as overall financial flows to developing countries surged. Lending jumped after the 2008 crisis, with record \$44 billion commitments in FY 2010 when the crisis peaked, before again ebbing to $\$ 20.6$ billion in FY 2012 and diminishing further to $\$ 15.2$ billion in FY 2013, close to the average of $\$ 13.5$ billion between 2005-08. Although this temporary increase demonstrated the Bank's capacity for counter-cyclical lending, these trends are also indicative of an institution whose lending has been stymied by the capital constraints on the one hand and high transaction costs in lending on the other, the first limiting supply and the second limiting demand.

Increased lending can only be achieved in principle either through an increase in capital to support new loans, or through an increase in the funds that it borrows from the bond markets in order to make more loans (i.e. increase its leverage or the amount borrowed relative to the equity it holds). Over the last few years, the IBRD has done both. It has increased capital, and it has increased leverage. This has enabled it 
to increase effective lending materially over the crisis period, by increasing its net loans outstanding from USD 99 billion to USD 141.7 billion in the period 2008 to 2013, following stagnation over the previous 18 years.

With the on-set of the global crisis, the IBRD responded by significantly scaling up its lending operations and contributed to reducing the severity of the crisis, especially for developing countries shut out of frozen global capital markets. However, despite this increased lending during the crisis years, the reality remains that while the IBRD has an extremely well known franchise, its actual financial clout, in terms of global disbursements, is extremely modest. To give a rough scale of size, the total loan outstanding to the non-bank sector, by banks, in developing countries is USD 1.14 trillion (as of Dec. 2011). ${ }^{1}$ In comparison, the IBRD loan outstanding (including undisbursed loans) was USD 199 billion as of June 2012. ${ }^{2}$ If we compare the lending even in the IBRD's countries of focus, we see that the IBRD lending is a small fraction of the lending conducted by the banking sector; it is also notable that the increase in lending of the IBRD in real terms has decreased relative to the global growth in lending. ${ }^{3}$

The relative slow pace of loan growth can be tied directly to difficult constraints both in terms of how the IBRD manages its leverage and equity increases - the gearing ratio has stayed materially unchanged, and there have been only four equity raises since the inception of the World Bank - a period which has seen four global recessions. ${ }^{4}$

This paper seeks to outline the internal and external constraints to capital and gearing, and examines why such constraints have arisen. Subsequently, the paper examines some options that could overcome these constraints.

\section{The IBRD and the problem of equity}

In order to understand the constraints faced by the IBRD better, it is useful to understand both its history and in turn, the unique financial structure that underpinned the design of the IBRD. This structure was an innovative marriage that leveraged relatively modest public funds (its equity) with market borrowings (its debt). The public funds - only a small part of which was actually paid in - reduced the cost of funds and government guarantees ("callable capital" that could be drawn on, if the need arose) provided additional confidence to markets further reducing the cost of borrowings. The reliance on markets for the bulk of the IBRD's lendable resources not only ensured that the institution could be much larger than if it relied mainly on public funds, but also provided an external discipline that mitigated the politicization of the institution by its owners.

When the IBRD was founded, the member owners put in USD 10 billion, of which $20 \%$ was actually paid-in, while the remaining $80 \%$ of the banks 'capital' base was callable - an obligation by the member countries to inject capital as the need would arise. Since the inception of the IBRD in 1945, there have been the four capital increases (1959, 1979, 1989 and 2010), in which member countries have put in increasingly larger proportions of capital as 'callable'. Prior to the most recent capital increase in 2010, the subscribed capital of IBRD stood at USD 190 billion, of which 94\% was callable capital. In April 2010, member countries agreed to raise its capital by USD 86 billion of which USD 81 billion was in the form of callable capital, while paid in capital was only $6 \%$ of the total increase ${ }^{5}$.

There are two important points to note about the trend that 'subscribed capital' has taken over time. First, the equity injections to support growth have only taken place at significant intervals, even as the global economy expanded massively. This has lead to a significant erosion of the capital injected into the World Bank in real terms. These injections are low both in absolute terms, and, as evidenced in the case of the recent capital increase, also low relative to other multilateral development banks. ${ }^{6}$ 
Second, since the bulk of the capital increases are in the form of callable capital, other than providing a veneer of psychological comfort, its actual value is questionable. The Bank itself had internally recognized this reality at least since the early 1980s. If the callable capital were ever called in, it would effectively be a nuclear option - so devastating as to effectively destroy the Bank itself. Consequently, rating agencies use measures that are based on the Bank's "useable" capital. This is an issue that is expected to grow in magnitude - and will be examined later in this paper.

Given the limited equity injections over time, the lending disbursed by the IBRD has from the very beginning depended on being able to access financial markets and leverage its relatively thinly capitalized balance sheet. In this context even the most ambivalent observer would find it hard to challenge the fact that the IBRD has been immensely successful in leveraging its thinly capitalized balance sheet. This has been made possible through a combination of factors - the capital guarantees provided by 'strong' member countries, through obtaining a AAA rating early in its existence, and of course the general credit expansion boom (despite periodic interruptions) during the last six decades that allowed all financial institutions (and not just the IBRD) to increase their leverage.

All these factors enabled the IBRD to raise substantial funds at the lowest costs and build its reputation in international bond markets allowing it to access a range of currencies in multiple markets. A healthy net income combined with financial prudence led to retained earnings rapidly overtaking the paid-in capital in terms of share of capital. At the end of FY 2012, paid-in capital was just a third of the Bank's equity (which stood at USD 36 billion). This strong performance of earnings - in turn the result of exemplary repayment record of the borrowers - partially offsets the weakening trend of equity injections to support growth.

\section{The political framework results in the low equity injections observed}

A key question regarding the Bank's equity is why has capital been injected so infrequently and in relatively small amounts despite the promise of substantial leverage. Before we answer that, it is important to recognize that the IBRD membership has two blocs: emerging economies (or the erstwhile developing countries), who are the principal borrowers and are increasingly improving their position in the global order and demanding a louder voice; and the developed bloc comprising the richer countries who continue to own a majority of the IBRD and consequently possess control of the key levers of governance and organization reflecting an earlier age of global power, but whose own economic engine has been sputtering. While this political reality, as described above, is no doubt an over simplification of a more complex picture, the basic schism in ownership and attendant issues is well understood and is entrenched in all thinking about, and indeed by, the IBRD and member countries themselves.

The financial design of the IBRD required all member countries to contribute to the institution's capital, with the caveat that poor countries (the borrowers) had to contribute less, but then also had commensurately less power. The two principles - that power came with a price and there were no freeriders - ensured broad representation but strong creditor rights as well. Ironically, with the significant shifts in the balance of global power, the equity story of the IBRD faces a different 'free rider' problem today. In the past rich countries put brakes on IBRD capital increases because they did not want to the Bank to become so big as to crowd out private lenders and national agencies, whether private banks based in their countries or official Exim banks.

Today, however, private banks are struggling. If the IBRD is to increase its lending substantively and in a manner that is financially prudent, it needs to increase its capital. Emerging economies are willing to put in capital to do so, but only if their ownership rights increase commensurately. However, the rich member 
countries have been disproportionately affected by the crisis and find it difficult to increase their capital commitments due to growing fiscal deficits. At the same time they are unwilling to let the emerging market member countries increase their share of capital that threatens the majority voting power of the rich countries. While the recent capital increased the voting power of emerging countries, it was hardly the 'game-changer' it was alleged to be. For one the voting share of the emerging and developing countries was capped at a level that ensured that their share was below 50\%. Moreover, although in principle the 7 percent change in the voting shares was considerable, a large part of it was due to reclassification of what it meant to be a developed/ developing country?

"Before the voting power reforms of 2008 and 2010, the World Bank listed the aggregate voting power of developing countries as $40 \%$. At the end of voice reform the share of DTCs is $47.19 \%$ Almost half of this aggregate increase of 7.19 percentage points is a pure 'reclassification' effect, involving no voting power realignment' 8."

But the developing countries have only themselves to blame for the poor hand they played in the last General Capital Increase (GCI) of the Bank. While developing countries wanted a much larger capital increase of the IBRD, the G-7 countries were pressing for a substantial expansion of the IMF's quotas, to equip it with the resources necessary to rescue Europe. But the IMF requires a super-majority for a quota increase. (As per the Articles of the IMF "an eighty-five percent majority of the total voting power shall be required for any change in quotas.") While this has traditionally given a veto to its preeminent shareholder, the U.S., this is not always the case. It also grants veto power to major developing countries whose combined quotas exceed $15 \%$ which they had exercised with some dexterity in $1994 .{ }^{9}$ Major developing countries could have linked their support for the IMF's quota increase to the G-7's support for a larger IBRD GCI. But they failed to press their leverage.

An important consequence of the modest increase in the Bank's capital is that it seriously limits the role and impact the IBRD can have as a lender for core long-term projects like infrastructure as well as a counter-cyclical lender during times of systemic crisis. Looking ahead, it is worth asking if there is scope for financial redesign that can fulfil both the lending aspirations and yet manage to balance the conflicting stakeholder problem.

Within this, there are two broad approaches. The first is a short-term fix: if the political impasse makes an increase in equity infeasible for now, can the IBRD's leverage be increased? What would a 'reasonable' increase in leverage mean in real terms? Second, are there innovative measures one could apply to the way equity is raised by the IBRD? This would include a look at new instruments that could raise capital during future crises but could also attract support from the major shareholders. We argue that there are feasibly options drawing from market innovations in the contingent capital space, as issued by leading financial institutions in the wake of the financial crisis. The second consideration is to ask more fundamental questions around the structure of equity and voting rights, and if this can be changed to allow a more clear link between financial contributions and governance and control.

\section{Can leverage be increased?}

Increasing leverage within the IBRD requires us to examine two concerns. First, there is a widely held concern that even if risk appetite may permit an increase, this would impact the IBRD's AAA rating status, and consequently materially impact its funding costs. That is, the IBRD cannot increase leverage.

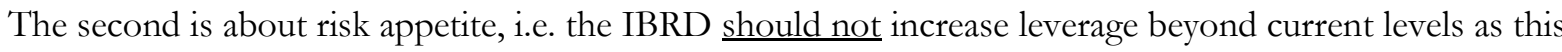
is unsafe. 
The AAA rating is indeed critical to the IBRD for three key reasons. First, the IBRD business model is wholesale funded, though with substantive equity. Second, it is unregulated by any regulatory authority. Third, it does not pose systemic risk and hence cannot rely on "too big to fail" bank bail-outs. It is a lending institution that depends on, and is in turn essentially regulated by, the bond markets. The rating status it enjoys is central to the ability to raise funds to finance operations.

Nevertheless, the IBRD is in a position to increase its leverage i.e. the ratio of borrowings to equity, and this can be done without a cost to its rating. A broadly equivalent way to look at leverage is to compare the equity in the Bank to the assets it supports.

The IBRD uses two measures that do this: the gearing ratio and the equity to loans ratio. The gearing ratio is the amount of loans on the asset side of the balance sheet to a measure of equity which includes not just on-balance sheet equity (reserves and paid-in capital) but also the guarantees provided by the member countries. The second measure compares the equity to loans excluding the guarantees by the member countries. The two measures are illustrated below (Figure1).

Figure 1: Measuring 'leverage'

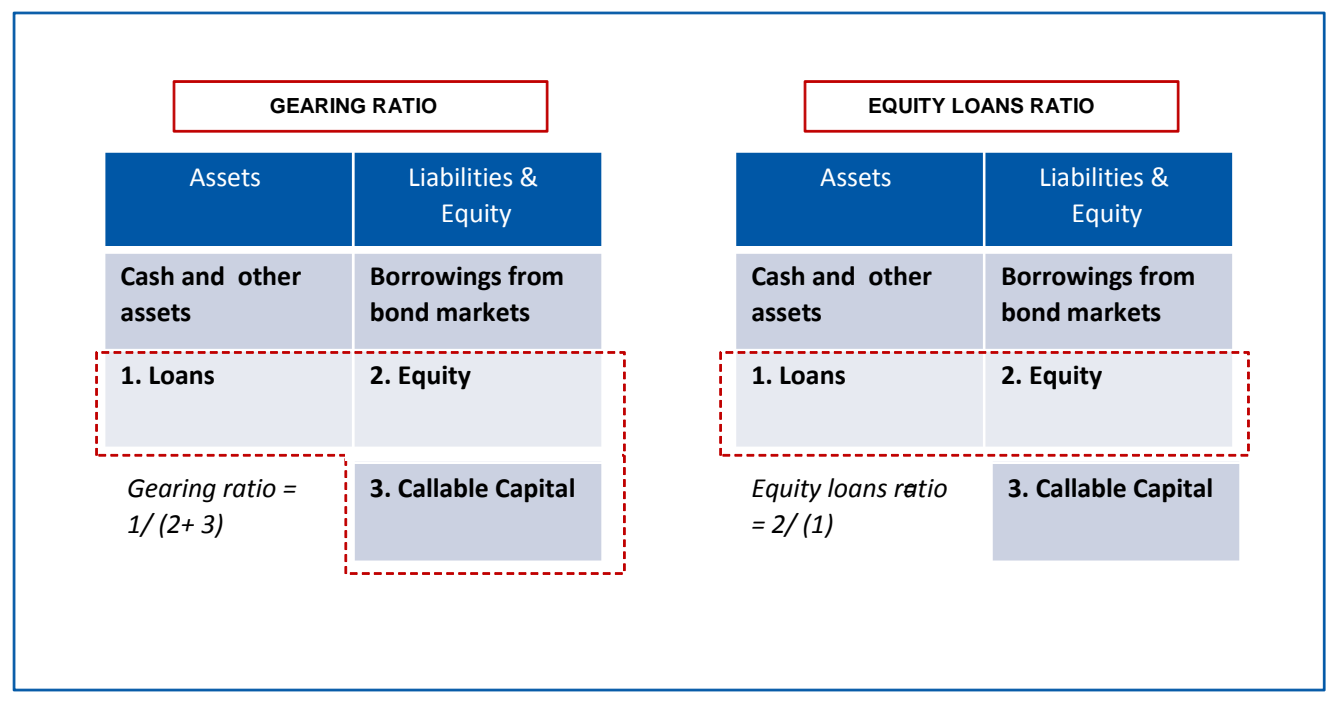

The gearing ratio is the traditional measure used to ensure conservative leverage in the IBRD, and as a measure, dates back to earliest days of the banks formation. The IBRD's Articles of Agreement set a limit on the gearing ratio at 100\%. ${ }^{10}$ As applied, this meant that the total amount outstanding of direct loans made by IBRD, including participation in loans and callable guarantees should not exceed the subscribed capital, reserves and surplus - "the statutory lending limit".

During the period 2008-2011, the gearing has increased from $45 \%$ to $60 \%{ }^{11}$. Thus, the IBRD operates well below even this conservative statutory lending limit. Therefore, the IBRD clearly 'can' increase gearing as per its Articles although obviously it would want to keep some headroom in case an unforeseen systemic crisis requires it to sharply increase lending.

Moreover, with more sophisticated methods of measuring the risk within the Bank, the gearing ratio has become an increasingly outdated and unsophisticated metric for measuring leverage. However, since the gearing ratio is reflected in its Articles, it still remains the pivotal point for debate. Furthermore, risk management has made considerable advancements since the 1950s, and both the IBRD and the rating agencies use metrics that look at available equity to measure capital adequacy. 
Specifically, the IBRD uses a long-term equity to loan target within which the bank must operate. Currently, this target is a range from $23 \%$ to $27 \%{ }^{12}$, i.e. the IBRD will ensure that it always has at least enough equity so that it covers roughly a quarter of the loans outstanding. Moreover, the IBRD has not optimized its lending to match its own target ratio, consistently holding more capital than is deemed necessary by its own internal policies. ${ }^{13}$ On the basis of the target ratio, the IBRD's projections indicate that it will only be able to lend USD 15 billion from 2014 onwards unless there is a capital raise or a breach of the internal $23 \%$ limit. ${ }^{14}$ There is also, as we argue later, a third option: increasing net income (by lowering administrative expenses) and transferring a greater fraction of net income to reserves relative to the current uses of net income.

\section{Cost of Debt Considerations}

As a starting point, since IBRD bonds are tradable in the markets, the yield they offer investors can be used as a metric of the perceived risk an investor faces, when investing in the bonds. Implied yields (as obtained from Bloomberg, $21^{\text {st }}$ August 2012) show the comparable yields on 5 year instruments of the IBRD and their peer group (Table 2). Looking at this comparison, we find that IBRD has the lowest yield of the multilaterals, implying that the markets for investment consider IBRD to be a very safe credit, even within the universe of multilaterals.

Table 2. IBRD and its peer group

\begin{tabular}{|l|l|}
\hline 5 Year Bond & Bond Yield $(\%)$ \\
\hline IBRD 04/17 & 0.82 \\
\hline EIB 03/17 & 1.15 \\
\hline EIB 06/17 & 1.13 \\
\hline EBRD 06/17 & 1.09 \\
\hline EBRD 02/17 & 0.91 \\
\hline AfDB 03/17 & 0.84 \\
\hline
\end{tabular}

It is also interesting to compare the perceived risk an investor faces, when investing in IBRD versus investing in government bonds of comparable time horizons. We have compared yields on 5 year instruments of the IBRD bonds to those of the five largest IBRD shareholders and the emerging economies. The IBRD bonds are as safe as the leading developed markets (Table 3), and (in most cases) significantly safer than emerging economies in which the IBRD invests (Table 4). The key message from these tables is that the IBRD's financial conservatism has positioned it as one of the safest financial investments.

Table 3. IBRD and its top 5 shareholders

\begin{tabular}{|l|l|l|}
\hline Country/ Institution & $\begin{array}{l}\text { IBRD shareholding } \\
\text { [Voting power }(\%)]\end{array}$ & $\begin{array}{l}\text { Bond yield } \\
(\%)\end{array}$ \\
\hline IBRD five year bond & $\mathrm{Na}$ & 0.82 \\
\hline United States & 16.05 & 0.79 \\
\hline Japan & 9.60 & 0.22 \\
\hline Germany & 4.40 & 0.48 \\
\hline France & 4.21 & 0.97 \\
\hline United Kingdom & 4.21 & 0.67 \\
\hline
\end{tabular}


Table 4. IBRD and Emerging Economies

\begin{tabular}{|l|l|}
\hline Country/ Institution & Bond Yield (\%) \\
\hline IBRD 04/17 & 0.82 \\
\hline Turkey & 7.97 \\
\hline Thailand & 3.31 \\
\hline Taiwan & 0.90 \\
\hline South Korea & 3.01 \\
\hline South Africa & 6.04 \\
\hline Russia & 7.57 \\
\hline Mexico & 5.10 \\
\hline \multicolumn{1}{|c|}{ Indonesia } & 5.45 \\
\hline India & 8.16 \\
\hline China & 2.99 \\
\hline Brazil & 9.20 \\
\hline
\end{tabular}

\section{Rating Agency Considerations}

In its early years the IBRD engaged in significant effort to obtain an AAA rating. ${ }^{15}$ In general, high ratings are very difficult to obtain, but once obtained, they are relatively less challenging to maintain. It is important to recognize that while rating agencies and financial markets look at the debt to equity ratio as a critical component in their analysis, they also consider a variety of other factors in determining their rating of an organization. Given that there is a difference between what the IBRD considers capital adequacy, and what the rating agencies call 'capital adequacy', its germane to ask if the IBRD could increase its leverage ratio without a ratings downgrade.

During 2011, the IBRD broadly maintained its debt/equity ratio at 3.4x in 2011. ${ }^{16}$ However, the important question that the IBRD needs to ask is the reverse - what was the benefit in terms of lending increase if the IBRD had increased its debt to equity ratio (the metric rating agencies look at as a measure of leverage) by $0.5 x$ ? ${ }^{17}$ This would increase lending by $10 \%$ of the debt it has on its balance sheet - an additional $13 \mathrm{bn} .{ }^{18}$

What determines ratings: Ratings are a complex and dynamic function of a number of determinants, which can be broadly divided into external support and intrinsic strength measures. The important thing to understand is that ratings are not absolute measures, but relative in nature. The strength of IBRD's rating should be therefore judged relative to its peer group. This is a crucial distinction. In order to understand MDBs better, rating agencies categorize multilaterals (MDBs) into two groups, the European banks and the international MDBs. So the comparator set for the IBRD includes Asian Development Bank, African Development Bank and Islamic Development Bank. Rating agencies look at EIB and EBRD separately. Whether this will change if the European crisis continues remains to be seen.

The IBRD ranks very high on both internal and external rating factors. This is conservative and in light of the potential uplift in lending possible, it is worth re-examination. Can the IBRD reduce its ranking on one or more of these factors, yet retain its credit worthy status? The answer appears that it should be possible. To achieve the AAA rating, an institution does not need to get the highest score across all the metrics. What it does need to do is optimize across metrics and actively choose to score higher in some metrics and lower in the others, and support these actions through a positive negotiation with the rating agencies in question. 
The IBRD lives today in a financial world where rating agencies and all financial institutions engage in a complex dialogue; a rating has as critical an impact on bank profitability as the ability to offer sensible credit, to operate at a low cost and to ensure strong governance. The IBRD has basically taken as a given that any change in leverage will necessarily adversely affect its ratings and hence it has taken the issue off the table. The alternative approach would be to start from the IBRD's financial strengths and the support it enjoys from its shareholders and then make the case why a modest increase in leverage would be advantageous and examine every feasible way to optimize its ratings and convince the ratings agencies.

In addition, looking at external ratings, the IBRD has a much stronger external rating compared to its peer group. Rating agencies look at two things in measuring strength of callable capital: the share of AAA rated callable capital providers and the number of holders who are in turn not borrowers. The IBRD ranks at the top in both of these metrics with $66 \%$ AAA/AA callable capital providers, compared to the average $35 \%$ in its peer group. ${ }^{19}$

The value of external support is something that comes with two important caveats. First, as pointed out earlier, from a bond market perspective, callable capital is virtually useless, as exercising would be tantamount to spooking funding sources and consequently undoubtedly sharply increase the cost of funds.

Second, from a long term perspective, it is unclear that the sovereign support directly translates into a 'strong' guarantee comparable to a bond backed by a single AAA country. First, it is backed by both AAA and non-AAA rated countries. Secondly, in a global recession, the rules (evidently) change. Unlike a bond issued by a single sovereign, where the threat of default and consequent downgrade has a material impact on the financial balances of the relevant sovereign, the callable capital of the IBRD is distributed too widely (and each commitment is arguably too insignificant) for a default to be translated into any serious threat to each individual contributor. As a thought exercise, imagine that there is a capital call for USD 10 billion and the UK reneges on its contribution of USD 700 million ( $7 \%$ of the total). It is clearly unfeasible to imagine a downgrade on the UK sovereign rating in this scenario, especially as this refusal to pay will likely occur not just in the UK, but across the board. To make matters more complex, there is no single court of law where legal recourse can be sought effectively and efficiently, if the IBRD defaults on its bond payments.

Despite overt protestations to the contrary by the IBRD's management, it has long been recognized both internally within the IBRD as well as by rating agencies that the value of the "comfort" that callable capital provided to capital markets has diminished considerably over time and what really matters is subscribed, rather than callable, capital. Thus a recent commentary from Fitch on the European MDBs stated,

"While member states are legally bound to respond to a capital call, the recent financial difficulties of certain European states have raised questions regarding their readiness to respond to such a call." 20

In recent years several OECD countries have seen a downgrade, casting further doubt on the usefulness of callable capital. However, this weaker equity contribution is offset by a stronger borrower base reflected in higher average ratings within the borrowing countries, thereby increasing the IBRD's financial health. The IBRD continues to be better positioned than peer institutions because of the broader base of borrower and non-borrower shareholders, a relative advantage that is unlikely to go away. ${ }^{21}$ 


\section{Internal strength}

Using a more conservative argument, the IBRD's financial strength should be looked at on a standalone (intrinsic) basis without any contingent support. What is an 'intrinsic basis'? It is essentially the ability of a lending institution to demonstrate a healthy and sustainable business model. While the rating agencies decompose this 'intrinsic basis' into a number of intuitive metrics, the key concerns with an increase in lending is the impact on "asset quality" - as the IBRD increases lending, would it increase the credit risk associated with the loans it makes?

In a conventional 'profit oriented' lending world, the only way a bank can rapidly increase lending and market share is by taking on higher risk (either by targeting riskier borrowers, or by reducing the price of its loans). The IBRD lends to countries, and its preferred creditor status has meant that borrowers give priority to repaying their obligations to the IBRD. The IBRD has never declared a loan loss, although non-accruals have sometimes persisted.

The Bank's strong record on asset quality reflects, in part, policies to mitigate credit risk. In addition, it manages risk by country lending limits to manage concentration risk. For instance the single-borrower exposure limit for FY 2011 was USD 17.5 billion for India and USD 16.5 billion for the other largest borrowing countries deemed to be the most creditworthy by the IBRD. There also is an equitable access limit of $10 \%$ of IBRD's subscribed capital, reserves and unallocated surplus (USD 22 billion at end-FY 2011), and the overall country limit is the lower of the single-borrower exposure and the equitable access limit.22 As of June 30, 2012, no borrowing country was at that level. There is also a statutory lending limit, whereby the total amount of outstanding loans and callable guarantees cannot exceed the sum of subscribed capital, reserves and surplus; at the end of FY 2012 the Bank's exposure was 58\% of this limit.

In addition, it must be noted that compared to peer group, the IBRD has, by a significant margin, the highest return on equity - therefore, on both current core capital levels, as well as future expectations of capital increase without additional commitments, this is a measure of future capital strength. As evidenced by the metrics and trends on profitability, the IBRD has outperformed the peer group through the global financial crisis. ${ }^{23}$

The IBRD has tried some degree of financial engineering to, for instance, get around its constraint for managing IBRD exposure to large borrowers close to the Single Borrower Limit (SBL). In 2003 it authorized the purchase of Special Private Bonds (SPPBs) when Bank exposure to China was approaching the SBL. Under this framework, the Bank exposure to a country can exceed the SBL without additional risk to the Bank as exposure in excess of the SBL is protected by the purchase of an equal amount of SPPBs by the country. Thus, Bank exposure to a country could exceed the SBL on a gross basis but stay within the SBL on a net basis. As a result, the Bank does not have to hold additional capital for exposure above the SBL. In 2012, the Bank approved the use of SPPBs (capped at US $\$ 4.3$ billion in excess of the SBL) by India which would increase its gross exposure to India but on a net basis, the exposure will remain within the SBL. Nonetheless such attempts have had at best a modest effect on what is a deep structural problem.

To conclude, this provides reasonable grounds for the IBRD to engage in discussions with rating agencies around the possibility of moving the gearing ratio. What are the risks to this approach? Ratings agencies are hardly perfect, and of course, they are often behind the curve. But rating agency views (good or bad) apply to all MDBs, and ratings are a relative measure. The IBRD has become too risk-averse. It needs to first push itself from its existing comfort zone on its own risk appetite and decision making and needs to think of and treat ratings as a variable it has to optimise rather than as an externally binding and 
immovable constraint. The bottom line is that increasing the IBRD's leverage modestly is possible and the institution needs to be pressed to move on this score.

\section{Changing the IBRD approach towards capital optimization}

The Equity to Loans ratio (ETL) is the single most important operational metric within the IBRD. As the IBRD has limited access to increasing capital, this metric is the key determinant of leverage and consequently the amount of lending increases by the IBRD.

The ETL ratio ${ }^{24}$ is designed to ensure two outcomes:

i) The IBRD should have enough capital to withstand the income loss if a major borrower (or set of borrowers) fails to repay while continuing to service its bondholders without having to seek recourse to 'callable capital'.

ii) The IBRD should be able to support loan disbursements even after a shock (reflecting the mandate of the IBRD as a development institution to be a source of counter-cyclical financial flows).

The IBRD uses a single metric to meet the two targets. From the point of view of the bond markets (and the rating agencies), who care primarily about financial losses this implies that the IBRD is overcapitalized. This is because market actors (e.g. rating agencies and bond markets) do not care if the World Bank fails its development mandate during a crisis; what they do care about principally is the institution's ability to keep its fiduciary obligations to its bond holders. In addition, they would need transparent mechanisms in place to allow for a capital injection in the event of stress, and further in the event of such capital not forthcoming, a well-planned and phased wind-down. These requirements raise two questions with regards to the Bank's capital adequacy.

1. How much capital does the IBRD need to support today's loan book, in order that there is enough capital buffer to cover losses during a stress scenario, and bondholder risks are covered? In other words, if there is a stress, how much capital should the IBRD hold, assuming there is no pressure to grow its loan book when it is financially stressed?

2. How much do the shareholders want the institution to grow, especially in the event of shock? This should determine the capital required to grow the business, and determine the amount of contingent capital instruments one should put in place.

This approach allows the IBRD to better optimise its capital structure to truly reflect the risk it holds on its books. It should either hold much lower capital than it currently does, or lend more given its overcapitalized position. There is a however, a counter-argument, namely that the Bank needs to hold extra capital in case an unforeseen systemic crisis requires to it sharply increase quick disbursing loans. However, in that case there is a better option. Instead of holding excess capital against unforeseen contingencies, a financial redesign should ensure that additional capital can be injected automatically when capital is most needed by the institution. This option, however, has its own problems. The Bank's Articles state that the "capital stock may be increased when the Bank deems it advisable by a threefourths majority of the total voting power", which requires a broad consensus. Moreover, only in the case of the IBRD (not the other MDBs), U.S. law requires that Congress give its assent before the United States can vote in favour of a capital increase in the Board. In a world in which financial developments and market sentiment can change rapidly, these requirements can delay a capital increase to the point of precipitating the very crisis they are mean to prevent. 
However, there is an opportunity to delink the provision of capital from existing shareholders to enable better pricing of this capital. In essence, the IBRD should seek to tap into a new class of capital providers which allows it to obtain more high quality capital at a low price, which in turn allows it to meet its lending goals. The starting point of course is to ensure future ownership in the hands of owners who have an aligned interest in the growth and mission of the organization. The second consideration is to ensure that shareholders pay a premium for their enhanced ownership.

This can be done in a variety of ways from the use of new share issuances, to contingent capital instruments, to directly auctioning voting rights which we discuss next. These innovations would allow a more efficient pricing of capital where capital providers selected are the ones who need the IBRD to grow in times of crises, who are willing (and able) to put money into it, who consequently get more control of the institution, and finally and most importantly, pay a premium price for the ownership they receive.

In comparison, the current capital structure, based on voting rights assigned to callable capital is weak for several reasons. First, any effort to raise capital via a call on the 'callable' capital has become, in today's world, a high risk event, which has to be priced in by the Bank in its stress tests. As a result the IBRD has to hold additional capital to ensure that there is little chance of it ever seeking recourse to callable capital. Second, during a crisis, this capital structure further creates damage by conferring disproportionate rights to the 'callable capital' providers, who can actively block any new infusion of capital at any time. Third, it forces the Bank to improperly price risk through the cycle, and consequently bear higher costs through lower lending. That is, during good years the IBRD holds more capital than required due to the fact that IBRD has an inefficient capital structure that gets severely exposed during crises.

\section{Fundamental redesign: Insight from the mutual model}

Several design features of the Bank have contributed to its historical evolution as one of the most robust international financial institutions, its many limitations notwithstanding. At the outset, the IBRD was created through visionary support from a group of member countries, notably the US, who during the first few decades of the Bank's history gave it the capital, strong management support, and most importantly, the political backing to ensure its survival and allow its growth. Borrowing countries also had to contribute capital, albeit in modest amounts. This structure ensured there would be no free-rider problem - power and privilege came at a price.

Over time the IBRD has demonstrated another core strength whose value has been unrecognized borrowers, a large group of poor countries, assiduously repaid the Bank loans both through internal and external crisis, and typically over and above any other commitments they would have, reflecting the preferred lender status given to the IBRD. This is reflected in the remarkably low level of arrears, as well as consequently the steady increase of retained earnings. Retained earnings net of loss reserves had reached USD 29 billion in 2012. At nearly 2.4 times the paid-in capital by member countries (USD 11.7 billion) it supports a significant part of the lending activities of the Bank. ${ }^{25}$ Indeed these retained earnings would have been substantially higher were it not for two developments. One, since the early 1990s, as result of pressure from non-borrowing developed countries the Bank put in layers of additional checks and balances, some justified but a lot of it gold plating that both increased transaction costs for borrowers and, by adding to administrative expenses, reduced the Bank's net income, and thereby its ability to transfer to reserves. Second, the rich countries put pressure for the Bank's net income to be used for all sorts of purposes, some more worthwhile than others (of which large transfers to IDA have been the most notable), again reducing transfers to reserves. ${ }^{26}$ 
The third factor that has changed is the slow but marked global rebalancing that has occurred over the past two decades wherein the Bank's borrowers' financial health has improved even as the financial health of its major OECD shareholders has deteriorated. This is reflected in the higher country ratings of the borrowing countries, which in turn means that as the average credit risk has reduced, it costs the Bank less to lend to the same borrower group, as it has to hold less capital against such lending activity. The flip side of global rebalancing, however, is that there are, on average, poorer ratings received by several OECD countries, which is reflected in a broad sense in both the reduced ability to contribute equity, as well as the devaluation of the value of the 'callable capital' in the Bank.

The current equity structure, which gives voting rights to the majority shareholders in the capital structure, does not (and cannot) take into account the latter two developments. The issue is structural, in that the IBRD is a development bank, which has an equity and ownership structure that is more typical of a market based company. For a market based company, lower arrears and higher credit quality are priced into the equation for both the borrower, who faces a lower interest cost, and for the equity owner, who, among other things, has to hold lower capital and obtain higher returns on their capital. It may be worth considering other structures of ownership that are more appropriate for non-profit oriented groups of borrowers and lenders. A natural comparison may be drawn to the Mutual Societies in the UK, which are owned by both the savers and the borrowers. Essentially the bank is owned by the individuals who lend or save with the organization. These individuals are given membership into the mutual, and receive points based on their contribution to the sustainability of the enterprise.

In principle, the success of the mutual banks (which want to provide a lasting service to their members) and of the market banks (which want to return profits to their owners) both depend on having a satisfied customer base. Hence it can be argued that from a long run sustainability point of view, a good mutual has to be a well run bank. However, there are some interesting governance architectures that offer lessons for the IBRD. This does not need a complete transformation of equity structure, but on a going-forward basis, can include mutual elements into the equation. One possible structure is as follows (simulated numbers are spelled out in Table 5):

- The current equity holders' equity stake in the IBRD would continue to be based on current ownership, and as a starting point, they would continue to own $100 \%$ of the equity as it stands today.

- Additional ownership/governance rights would be provided to borrowers from the Bank based on future borrowings (and servicing their financial obligations).

- There is an interesting consideration in the calculation of additional governance rights: It must be recognized that the success of the IBRD is a function of both the equity providers, as well as the borrowers' repayment record.

- A simple example would be that under a $20 \%$ equity to loans ratio, the equity holders have to provide USD 4 million for each USD 20 million that is lent. This USD 20 million, after tax and expenses, typically makes $1 \%$ a year (i.e. USD 0.2 million), for a period of five years.

- Therefore over the five years, the assets contribution to equity is USD 1 million.

- A simple and fair rule of thumb would argue that for every USD1 million of earnings, which is created by both the borrower and the equity provider, one could divide the voting rights in equal 
proportion. In this case, as the equity holder does not receive any of the financial benefits a 'saver' does in a mutual, the equity holder will receive a larger degree of points.

- The equity providers' initial points and rights would of course be independent of IBRD's performance, whereas the borrowers' points would depend only on the successful repayment of the loan, and be potentially provided at the end of the period.

- There would, however, need to be some assurance that earnings from new lending are not undermined by large administrative expenses imposed at the behest of large non-borrowing share holders.

Table 5. Financial Redesign: The Mutual Fund Model

\begin{tabular}{|lrrrrrr|}
\hline Basic assumptions & Year 0 & Year 1 & Year 2 & Year 3 & Year 4 & Year 5 \\
\hline Equity/ Loan ratio & $20 \%$ & & & & & \\
New lending (\$) & 20 & & & & & \\
Equity required for new lending & 4.0 & & & & & \\
Earnings from new lending & & 0.2 & 0.2 & 0.2 & 0.2 & 0.2 \\
\hline Total equity on balance sheet & 4.0 & 4.2 & 4.4 & 4.6 & 4.8 & 5.0 \\
\hline & & & & & & \\
Contribution of equity holders & $100 \%$ & $95 \%$ & $91 \%$ & $87 \%$ & $83 \%$ & $80 \%$ \\
Contribution from earnings & $0 \%$ & $5 \%$ & $9 \%$ & $13 \%$ & $17 \%$ & $20 \%$ \\
Borrowers share (50\%) & $0 \%$ & $2 \%$ & $5 \%$ & $7 \%$ & $8 \%$ & $10 \%$ \\
& & & & & & \\
llllustrative voting rights & $100 \%$ & $98 \%$ & $95 \%$ & $93 \%$ & $92 \%$ & $90 \%$ \\
Voting rights to equity holders & $0 \%$ & $2 \%$ & $5 \%$ & $7 \%$ & $8 \%$ & $10 \%$ \\
Voting rights to borrowers & & & & & & \\
\hline
\end{tabular}

\section{Contingent capital}

Another possible area of financial redesign is with regards to contingent capital. This issue has been discussed in the Bank after the 2008 crisis. In its spring 2009 communique, the Development Committee asked the World Bank group to "review the financial capacity, including the capital adequacy, of the IBRD and IFC". This was followed by an updated review request in the December communiqué, which specifically asked to "address all possible contingent capital approaches as well as keep in mind the special infusion of capital that would come from a special increase for voice reform".

At the time of the review, two types of contingent capital instruments were considered. One was the idea of pay-in. In the event of a crisis, and a breach of the E/L ratio, members would be obligated to pay in equity. The second was a pay-out. In the event a breach didn't occur, excess capital would be repaid to the members.

The pay in structures included a GCI with only callable capital, with a trigger to pay-in if the E/L ratio is breached. Secondly, the IBRD considered an instrument comprising a GCI with only callable capital, and a smaller component of convertible debt (issued by the Bank to providers). This debt would convert into equity in the event of a breach. In the meantime, it would earn the providers the US treasury rate. 
The pay-out structures looked at different ways of deploying the excess capital, should the equity to loans ratio not be breached. These included directly returning capital to shareholders via either dividends or cancelling shares, remitting to the IDA, or investing the excess capital in a long term portfolio.

After robust debate on the usage of contingent capital, it was considered infeasible in 2010 to use contingent capital. While each structure had specific issues, the main reasons for rejection of contingent capital can be narrowed down to five.

First, the obstacles in enforcing compliance: any contingent capital measure requires dependence on future governments to enforce the structure. Although this could conceivably be done through legislation today that aims to ensure future compliance, assuming that future governments would comply might be wishful thinking at least in some cases.

Second, market based arguments arising from uncertainties that if triggered, markets might reassess the entire callable capital structure and react negatively if dividends were released in payout structures.

Third, concerns were voiced over possible technical complexities. There are several accounting and contractual complexities that are a natural by-product of a relatively complicated financial product.

Fourth, there were worries voiced over the potential risks borne by purchasers of contingent capital instruments. Contingent capital leads to an uncertain timing of the capital call, while at the same time, does not yield a budgetary benefit. In some cases, such as convertible debt, this may even lead to upfront budgetary costs.

Finally, the IBRD was concerned about the implications for its own autonomy. Using contingent capital structures also reduces the flexibility of the IBRD. For instance, hardwired redemptions (for payout structures) lead to reduced flexibility for the IBRD in case a trigger is breached. Moreover, without certainty of capital payments, it is difficult for the IBRD to make loan commitments.

These arguments all demonstrate that contingent capital instruments (cocos) are not something to be taken lightly. As complex products, coco's require care to execute, monitor and critically enforce in the event of a trigger. That said, in the recent years, the market has seen a host of coco issuances since 2010. The IBRD is in a strong position to leverage the significant research and debate that has been taking place amongst the banking and global regulatory community amidst the development and deployment of these cocos. Still there hasn't yet been significant exercise of triggers in these instruments, and in that regard, these instruments are untested.

A fundamental problem in the approach to using cocos was an inability to articulate the crucial dynamic at work. In the IBRD today, the current majority owners are neither willing to change the status quo of ownership, nor able to finance the growth of the Bank to allow it to achieve its mission. Conversely, emerging markets are jockeying for greater voice, which in effect means that they are willing to buy a larger equity stake. A contingent capital instrument issued by the IBRD could well lead to a situation where a repeat of the 2008 crisis leads to an inability of the developed market coco holders to make good on their payments, and in such a scenario, control could shift to emerging markets who would receive equity for their capital.

A possible way out of this impasse would be for the IBRD to take advantage of this dynamic and seek to appropriately price in the desire of some shareholder for greater control by auctioning additional issuance of equity and getting the highest price for control. Cocos can be successfully deployed for this purpose. 
The key to developing an efficient outcome for the IBRD to use cocos to raise additional capital is to recognize that all members should not be forced to participate in the raising of new capital. In the IBRD internal discussions, the presumption is that all countries have to participate in such a structure. This misses the fundamental dynamic that lies at the current impasse. Consequently, if in the event of a crisis, some emerging markets are both 'able' and 'willing ' to pay up for a chance at obtaining additional shares, the IBRD has an opportunity to use a market mechanism to price global power: create an auction mechanism for additional shares to raise the maximum amount of capital for modest changes in the governance structure, allowing the price mechanism to test just how much large countries are willing to pay for more power in the global system - and strengthening its own capital in the bargain.

\section{Conclusion}

The IBRD's financial design was an ingenious balance between power and purpose, while imposing only a moderate financial burden on governments. But as it often happens, the world changes much faster than institutions and this has been the case with the Bank as well. In a world in which net private capital flows to developing countries has been touching USD one trillion, the Bank's 2-3 percent odd share is indicative of just how modest its role and relevance is becoming.

This is particularly the case for infrastructure projects which require precisely the kind of long-term capital that the IBRD was set up to provide as well as the relatively reasonable degree of neutrality, probity and analytical skills that became the institution's core competencies. Today's emerging markets require massive new infrastructure investments as seen from the following:

- According to the ADB, "Asia will need to invest approximately USD 8.22 trillion in overall national infrastructure for energy, transport, telecommunications, water, and sanitation from 2010 to 2020 ". ${ }^{27}$

- It is estimated that of the USD 93 billion of investment needed annually for Africa's infrastructure, only about half will be forthcoming. ${ }^{28}$

- According to the United Nations Economic Commission for Latin America and the Caribbean (ECLAC), "The total infrastructure gap in Latin America - the difference between existing and needed investments - is a whopping USD 170 billion per year to 2020 ". ${ }^{29}$

Despite the massive infrastructure demands, total IBRD lending for infrastructure in FY 2012 was under USD 10 billion, a meagre amount when compared to the actual needs of these regions.

Even as the IBRD falters, emerging markets are stepping in, most notably China. According to the Financial Times, "In 2009 and 2010 China lent more money to developing countries than did the World Bank. While the World Bank made loan commitments of USD 100.3 billion from mid-2008 to mid-2010 in response to the economic crisis, China Development Bank and China Export-Import Bank signed loans of at least USD 110 billion over the same period." 30 By mid-2013, after more than half-century of lending, total outstanding World Bank loans to Africa (IBRD plus IDA) were just above $\$ 40$ billion while Chinese investments, in less than a decade, exceeded $\$ 100$ billion.

Since 2005, China has provided loan commitments upwards of USD 75 billion to Latin American countries. China's loan commitments of USD 37 billion in 2010 were more than those of the World Bank (USD 14 billion), Inter-American Development Bank (USD 12 billion), and United States Export-Import Bank combined for that year. ${ }^{31}$ The assets of Brazil's principal source of long-term lending, BNDES, are four times greater than those of the World Bank. 
The most recent development is the proposed BRICS bank. If the BRICS bank is to be a partnership of equals, then each country has to put in roughly equal amounts of capital. But then its size will be determined by its weakest member and it will be too small to matter. And if it is large enough to matter then either its membership will have to include existing major powers, which will make it similar to existing IFIs, raising the question why reinvent the wheel? If not, only one of the BRICS has the financial clout to make it happen - China. If so it is only reasonable that China will—as the US had done seven decades ago-ask for commensurate say in the institution's governance which others are unlikely to accede to. These tensions have led to a scaling back of the proposed BRICS bank's capital from $\$ 100$ billion to $\$ 50$ billion and thorny issues such as location, leadership and management are still unresolved. Nonetheless, the fact that even though the BRICS bank is a second best option, it is likely to come into being, a testimony to the frustration of the emerging powers with the status quo.

The long-term stagnation of IBRD lending, coupled with the entry of a host of new players, from emerging markets to Sovereign Wealth Funds, cast doubts on the World Bank's relevance in today's world. And as the recent calls for a BRICS bank make evident, the need for a World Bank-like institution has not diminished. It is just that the World Bank itself has diminished. This paper offers four suggestions to increase the volume of IBRD lending without massive new injections of funding by major shareholders (which will simply not be forthcoming).

First (although this was not discussed in the paper), the IBRD needs to innovate with new financial instruments that "crowd in" private investors. In recent years it has moved beyond "plain vanilla" loan products to innovating with contingent credit lines, catastrophe bonds etc.... Yet efforts to use credit enhancement guarantees that provide partial guarantees such as on local-currency issued by companies to finance infrastructure projects have only been modestly successful. In principle this should boost the credit rating of a typical infrastructure project to investment grade allowing cash-rich pension funds and insurers, which can only invest in assets graded AA or above, to buy the bonds and result in the project developer replacing bank debt with bonds (in turn allowing banks more room to provide loans to other businesses). In practice because the Bank counts guarantees the same as it does an actual loan, there is little incentive for a borrower to ask for a guarantee rather than a loan. Pricing guarantees and including only that rather than the face value of the guarantee in the leverage ratios would help crowd-in private resources. This might require a change in the IBRD's Articles.

Second, the IBRD's net income-its sources and uses—-needs far greater attention, since augmented net income transfers builds up the IBRD's equity, and hence its capacity to lend. The net income can be enhanced by reducing administrative costs and reducing transfers for other purposes. Given the fiscal situation in the DAC countries there will be considerable pressures for enhanced transfers from the IBRD's net income to boost future IDA replenishments which is inimical to the interests of IBRD borrowers (the MICs) and a negation of the "mutual fund" model of the IBRD. This could be preempted by ensuring that the IBRD net income was used solely for financing Global Public Goods, which benefits all members in the aggregate but whose marginal benefits will be maximum for poor countries/people.

Third, the IBRD should increase its leverage, albeit modestly. Certainly, the proposal to moderately reduce its equity-to-loan ratio may be provocative but the Bank needs to test the waters and press forward on this rather than simply sit back and say it would jeopardize its coveted AAA rating. To continue to harp on this position in its seventh decade is not just being needlessly risk averse, but also intellectually lazy. 
Fourth, given the IBRD's excellent credit-rating, it needs to leverage other financial instruments. The use of contingent capital, a possibility that has been considered (and rejected), can substantially enhance the IBRD's ability to finance new operations. However, instead of asking all members to contribute, it should consider creative possibilities like auctioning new shares to allow countries with greater resources and commitment to increase their contribution to the institution. This would not only serve to increase the amount of capital available to the IBRD to finance its lending operations, but also reflect more accurately the new realities of the global economy.

The changes proposed in this paper are not simple. Were they so they would have already been made. But if the World Bank is to retain its preeminent position in promoting global development it has little choice but to grasp the nettle, or risk fading away.

\section{Appendix}

Table A1: IBRD lending activity (1990-2012)

\begin{tabular}{|lll|}
\hline Years & $\begin{array}{l}\text { Loans outstanding } \\
\text { (USD, billion) }\end{array}$ & $\begin{array}{l}\text { Change in loans } \\
\text { outstanding }(\%)\end{array}$ \\
\hline 1990 & 99 & 7 \\
\hline 1997 & 106 & $(4)$ \\
\hline 2002 & 122 & 2 \\
\hline 2007 & 98 & $(5)$ \\
\hline 2008 & 99 & 1 \\
\hline 2009 & 106 & 7 \\
\hline 2010 & 120 & 14 \\
\hline 2011 & 132 & 10 \\
\hline 2012 & 136 & 3 \\
\hline
\end{tabular}

Table A2: IBRD lending activity to top 6 countries (USD billion)

\begin{tabular}{|llll|}
\hline Countries & Lending by IBRD & $\begin{array}{l}\text { Global Lending to Non- } \\
\text { bank sector }\end{array}$ & $\begin{array}{l}\text { Lending by major Regional } \\
\text { Development Bank }\end{array}$ \\
\hline China & 13 & 117 & 12 (ADB) \\
\hline Turkey & 13 & 72 & $\mathrm{Na}$ \\
\hline Mexico & 12 & 56 & 10 (IDB) \\
\hline India & 11 & 75 & $11(\mathrm{ADB})$ \\
\hline Brazil & 10 & 88 & 15 (IDB) \\
\hline Indonesia & 9 & 30 & $10(\mathrm{ADB})$ \\
\hline
\end{tabular}

Table A3: IBRD lending activity, by geographic region

\begin{tabular}{|lll|}
\hline $\begin{array}{l}\text { Geographic Area } \\
\text { (USD billion) }\end{array}$ & $\begin{array}{l}\text { Global Lending to Non- } \\
\text { bank sector }\end{array}$ & $\begin{array}{l}\text { Lending by } \\
\text { IBRD }^{37}\end{array}$ \\
\hline Africa \& Middle East & 265 & 11 \\
\hline Asia and Pacific & 368 & 39 \\
\hline Europe & 264 & 38 \\
\hline Latin America/Caribbean & 245 & 45 \\
\hline
\end{tabular}


Table A4: Ranking of the World Bank among Global Banks, selected years (By Assets)

\begin{tabular}{|lllllll|}
\hline Institution $^{38}$ & 1952 & 1960 & 1972 & 1984 & 1995 & 2008 \\
\hline IBRD & 8 & 4 & $<10$ & 27 & 68 & 68 \\
\hline IBRD+IDA & $\mathrm{Na}$ & $\mathrm{Na}$ & 7 & 10 & 41 & 47 \\
\hline
\end{tabular}

Table A5: IBRD: Debt, Equity and Reserves

\begin{tabular}{|lllll|}
\hline Years $^{39}$ & $\begin{array}{l}\text { Equity } \\
\text { (USD billions) }\end{array}$ & $\begin{array}{l}\text { Reserves and Surplus } \\
\text { (As \% of equity) }\end{array}$ & $\begin{array}{l}\text { Paid-in Capital } \\
\text { (As \% of equity) }\end{array}$ & Equity/Debt \\
\hline $1955-56$ & 1.1 & 19 & 81 & 1.29 \\
\hline $1968-69$ & 3.2 & 44 & 56 & 0.86 \\
\hline $1981-82$ & 6.3 & 58 & 42 & 0.21 \\
\hline $1994-95$ & 25.5 & 69 & 31 & 0.24 \\
\hline $2010-11$ & 39.7 & 71 & 29 & 0.29 \\
\hline $2011-12$ & 36.7 & 67 & 33 & 0.27 \\
\hline
\end{tabular}

Table A6: General Capital Increases of MDBs after the 2008 Economic Crisis

\begin{tabular}{|llll|}
\hline Institution $^{40}$ & $\begin{array}{l}\text { Capital base before } \\
\text { response to crisis } \\
\text { (billion) }\end{array}$ & $\begin{array}{l}\text { Proposed increase } \\
\text { (billion) }\end{array}$ & $\begin{array}{l}\text { Proposed } \\
\text { increase } \\
(\%)\end{array}$ \\
\hline IBRD & USD 190 & USD 86 ${ }^{41}$ & 31 \\
\hline ADB & USD 55 & USD 110 & 200 \\
\hline AfDB & USD 33 & USD 63 & 200 \\
\hline IsDB & USD 101 & USD 70 & 70 \\
\hline EBRD & EUR 20 & EUR 10 & 50 \\
\hline EIB & EUR 165 & EUR 67 & 40 \\
\hline
\end{tabular}

Table A7: Equity to Loans (ETL) Ratio for IBRD

\begin{tabular}{|ll|}
\hline Year & ETL Ratio $(\%)^{42}$ \\
\hline 2004 & 29.4 \\
\hline 2008 & 37.6 \\
\hline 2009 & 34.3 \\
\hline 2010 & 29.4 \\
\hline 2011 & 28.6 \\
\hline 2012 & 27.0 \\
\hline
\end{tabular}


Table A8: Strength of callable capital

\begin{tabular}{|ll|}
\hline $\begin{array}{l}\text { AAA rated } \\
\text { MDBs }\end{array}$ & $\begin{array}{l}\text { AAA-AA Callable Capital/ } \\
\text { Callable Capital43 }\end{array}$ \\
\hline IBRD & $66 \%$ \\
\hline ADB & $65 \%$ \\
\hline AfDB & $35 \%$ \\
\hline IsDB & $04 \%$ \\
\hline EBRD & $83 \%$ \\
\hline EIB & $66 \%$ \\
\hline
\end{tabular}

Table A9: Top 10 shareholders. S\&P Long term foreign currency sovereign ratings, 2002-2012 ${ }^{44}$

\begin{tabular}{|lllll|}
\hline Country & 2002 & 2012 & Outlook for the future & Change in last 10 years \\
\hline US & AAA & AA + & Negative & Reduced \\
\hline Japan & AA- & AA- & Negative & No change \\
\hline Germany & AAA & AAA & Stable & No change \\
\hline France & AAA & AA+ & Negative & Reduced \\
\hline UK & AAA & AAA & Stable & No change \\
\hline China & BBB & AA- & Stable & Improved \\
\hline Russia & BB- & BBB & Stable & Reduced \\
\hline Canada & AAA & AAA & Stable & No change \\
\hline India & Junk & BBB- & Negative & Improved \\
\hline Italy & AA & BBB + & Negative & Reduced \\
\hline Saudi Arabia & Na & AA- & Stable & No change \\
\hline
\end{tabular}

Table A10: Accumulated Loan Loss Reserves / Gross Outstanding Loans (\%) (5 $^{45}$

\begin{tabular}{|lllllll|}
\hline Institution & 2006 & 2007 & 2008 & 2009 & 2010 & 2011 \\
\hline IBRD & 2.22 & 1.97 & 1.38 & 1.54 & 1.29 & 1.17 \\
\hline ADB & 0.10 & 0.05 & 0.03 & 0.24 & 0.09 & 0.07 \\
\hline AfDB & 8.25 & 6.58 & 3.74 & 3.01 & 3.40 & $\mathrm{Na}$ \\
\hline IsDB & $\mathrm{Na}$ & $\mathrm{Na}$ & $\mathrm{Na}$ & 2.40 & 2.30 & 2.10 \\
\hline EBRD & 4.10 & 1.38 & 2.16 & 4.74 & 4.07 & 3.66 \\
\hline
\end{tabular}

Table A11: Five Largest country exposure / Total loans outstanding (\%) in 2011

\begin{tabular}{|ll|}
\hline Institution & $\begin{array}{l}\text { Five Largest Exposure / Total loans } \\
\text { outstanding }(\%)\end{array}$ \\
\hline IBRD $^{46}$ & 45 \\
\hline $\mathrm{ADB}^{47}$ & 68 \\
\hline $\mathrm{AfDB}^{48}$ & 77 \\
\hline EBRD & $\mathrm{Na}$ \\
\hline $\mathrm{EIB}^{49}$ & 55 \\
\hline
\end{tabular}


Table A12: Return on Total Assets (net operating income /total assets) ${ }^{50}$

\begin{tabular}{|llllll|}
\hline Year & IBRD & ADB & AfDB & IsDB & EBRD \\
\hline 2005 & 0.6 & 0.2 & 0.7 & 2.7 & 5.4 \\
\hline 2007 & 0.8 & 1.2 & 1.7 & 2.5 & 5.7 \\
\hline 2009 & 0.2 & 0.0 & 0.5 & 1.6 & $(2.8)$ \\
\hline 2011 & 0.3 & 0.6 & $\mathrm{Na}$ & $\mathrm{Na}$ & 0.4 \\
\hline
\end{tabular}

\section{Endnotes}

${ }^{1}$ Table 7B, Detailed tables on preliminary locational and consolidated banking statistics end-March 2012; http://www.bis.org/statistics/rppb1207 detailed.pdf

2 IBRD Financial statements and internal control reports , June 302011

http://siteresources.worldbank.org/EXTANNREP2011/Resources/8070616-1315496634380/81364901315496813876/IBRDFinancialStatementsandInternalControlReports.pdf

${ }^{3}$ See Table A1, A2, A3 and A4 in Appendix.

4 1975, 1982, 1991 and 2009.

See 'Tracking the global recovery', http://www.imf.org/external/pubs/ft/fandd/2012/06/kose.htm

${ }^{5}$ See Table A5 in appendix.

${ }^{6}$ See Table A6 in the Appendix.

7 'The World Bank used the DTC categorization (as used by the IMF) for the purposes of "voice reform", instead of the categories it normally uses- namely low-income countries, middle-income countries and high-income countries. As a result the shifts of voting power achieved in the Bank appear larger than they actually were. Also, countries like South Korea and Singapore - normally classified as high-income, advanced economies were classified as DTCs. These two countries were among the main receivers of the voice reform and without their reclassification the aggregate voting power shift from developed countries to DTCs in Phase 2 would have been $2.31 \%$ instead of $3.13 \%$. http://www.diis.dk/graphics/publications/reports2011/rp2011-05-world-bank-voicereform web.pdf

${ }^{8}$ http://www.diis.dk/graphics/publications/reports2011/rp2011-05-world-bank-voice-reform web.pdf

"The World Bank And The Emerging World Order Adjusting To Multipolarity At The Second Decimal Point," DIIS Report 2011.

${ }_{9}$ In 1994, the Managing Director of the IMF proposed a fresh issuance of 36 billion SDRs (Special Drawing Rights), the first since 1981. The G-7 opposed the increase on the grounds that there was no global need for extra liquidity and suggested instead a special one-off increase of 16 billion SDRs. Of this, about 5 billion SDRs would have gone to new members, chiefly Russia (1.5 billion) and other former Communist states. This would have helped the G-7 defray the costs for programs in East Europe that they would have otherwise had to bear directly through their own budgetary resources. The developing countries were willing to settle for a somewhat lower figure - a general increase of 30 billion SDRs. With the G-7 unwilling to compromise, developing countries feared that their interests were being sacrificed to special treatment for Russia (since the "systemic transformation facility" whose principal beneficiary was Russia also needed renewing that year), and blocked both. They could do so since the proposal required an 85 percent majority.

10 The original US proposal was to have the loans and investments of the bank to be limited to somewhere between $200 \%$ to $300 \%$ of its capital and surplus. However, the European member states and the Netherlands, in particular, insisted on a lower and more conservative 'gearing ratio', this was eventually negotiated at $100 \%$

${ }^{11}$ Financial Ratios, Moody's Credit Analysis, Feb 27, 2012, p. 11.

12 The IBRD's capital adequacy is agreed by the Executive Directors, who set the appropriate long term equity-to-loan target range. This target equity-to-loans range provides the context within which both annual net income allocation decisions, as well as in the assessment of the initiatives for the use of capital are made.

13 See Table A7 in the Appendix.

14 World Bank, "Medium Term Strategy and Finance Paper," SecM2011-0235, April 18, 2011. 
${ }^{15}$ See Devesh Kapur, John Lewis and Richard Webb, The World Bank: Its First half Century, Brooking Press, 2007, especially chapter 14 .

16 Moody's Credit Analysis, Feb 27, 2012, p.10. To get the debt/equity ratio we have calculated the ratio of 'Borrowings as a percentage of capitalization' and 'Sum of reserves and paid-in capital as a percentage of capitalization'. For 2010 and 2011, the figures are 3.46 and 3.41 respectively..

${ }^{17}$ Assuming on a conservative basis that $30 \%$ of the increased debt is held in cash and liquid assets.

${ }^{18}$ If the D/E ratio was increased from $3.5 \%$ to $4 \%$, it would effectively increase debt by $15 \%$, Assuming that a third of this increase is held in cash, then the remaining $10 \%$ of the debt increase can be lent out as assets. In 2011, the total borrowings at year end were $\$ 135 \mathrm{bn}$, soothe IBRD could conservatively have released an additional $\$ 13 \mathrm{bn}$ in assets.

${ }^{19}$ See Table A8 in the Appendix.

${ }^{20}$ Fitch ratings agency - Update paper on Supranationals, 14 June 2010, IBRD

${ }^{21}$ See Table A9 in the Appendix.

22 Moody's Credit Analysis, Feb 27, 2012, p. 6.

${ }^{23}$ See Table A10, A11, A12 in the Appendix.

${ }^{24}$ In practice, the IBRD forecasts performance for the future years, and applies a set of pre-agreed stress tests against this forecast, to assess the degree of capital available.

${ }^{25}$ Pg. 43, Balance Sheet, IBRD published financial statements 2011

To calculate 'Retained earnings net of loss reserves', we have subtracted 'Accumulated Other Comprehensive Loss' from the 'Retained Earnings' as quoted in the balance sheets

${ }^{26}$ See Devesh Kapur, "The Common Pool Dilemma of Global Public Goods: Lessons from the World Bank's Net Income and Reserves," World Development, Vol. 30 (3): 337-354, March 2002.

${ }^{27}$ Financing Infrastructure for Connectivity: Policy Implications for Asia; http://www.adbi.org/researchpolicy-brief/2011/07/11/4631.financing.infrastructure.connectivity.asia/ financing.challenges/

28 At the Fourth Annual U.S.-Africa Infrastructure Conference, 28 April

http://www.africancapitalmarketsnews.com/409/africa-needs-93-billion-a-year-for-infrastructure/

${ }^{29}$ http://latintrade.com/2012/03/latin-americas-infrastructure-gap

${ }^{30}$ China's Foreign Assistance in Review: Implications for the United states http://www.uscc.gov/researchpapers/2011/9 1 \%202011 ChinasForeignAssistanceinReview.pdf

${ }^{31}$ http://www.thedialogue.org/PublicationFiles/TheNewBanksinTown-FullTextnewversion.pdf

32 Financial Statements and Appendixes, published Annual Reports for 1990, 1997, 2002, 2007, 2008, 2010 , 2011

${ }^{33}$ IBRD Financial Statements, June 30, 2011

${ }^{34}$ Detailed tables on preliminary locational and consolidated banking statistics at end-March 2012, BIS Table 7B, http://www.bis.org/statistics/rppb1207_detailed.pdf

35 ADB annual report 2011, http://www.adb.org/sites/default/files/adb-ar2011-v2.pdf

Pg.52, IDB annual report 2011, http://idbdocs.iadb.org/wsdocs/getdocument.aspx?docnum=36736798

36 Table 7B, Detailed tables on preliminary locational and consolidated banking statistics at end-March 2012

${ }^{37}$ Pg.72 IBRD Financial Statements, June 30, 2011

Have used IBRD lending to 'Middle East and North Africa' + 'Africa' ; 'Europe and Central Asia'; East Asia and Pacific + South Asia' to compare with Global lending to 'Africa and middle east', Europe, Asia and Pacific respectively.

${ }^{38}$ Kapur et. al. Table 16-15 ; Financial Statements, The World Bank Annual Report 2008 ; http://www.relbanks.com/worlds-top-banks/assets-2008

${ }^{39}$ Kapur et. al. Table 16-9 ;

Pg. 33, Information Statement, http://treasury.worldbank.org/cmd/pdf/InformationStatement.PDF

40 Table 2, The ABCs of the General Capital Increase Todd Moss, Sarah Jane Staats, and Julia Barmeier http://www.cgdev.org/doc/IFI/IFI Briefs GCI-FINAL.pdf

For EBRD, See http://www.ebrd.com/pages/news/press/2010/100514b.shtml

For EIB, See http://www.eib.org/about/press/2009/2009-057-eib-capital-increase-of-eur-67-billion-takes-immediateeffect.htm

${ }^{41}$ The IBRD request is technically for a GCI/SCI of USD58.4billion (based on the existing shareholding structure) and a "selective capital increase" of USD 27.8billion, which alters slightly the shareholding weights. For simplicity, we have combined the two here.

${ }^{42}$ Capital Adequacy, Pg.5 , Moody's Credit Analysis, Feb 27, 2012. 
${ }^{43}$ Balance sheet summary and Capital Structure Summary, Moody's credit analysis. We have calculated the ratio of 'CC of AAA/AA Members' and 'Total Callable Capital'. For EBRD, see page 9 of Fitch's report. For EIB, See Pg. 8 Investor Presentation, June 2012.

${ }^{44}$ S\&P website, 2002 data from 'Sovereign Credit Ratings Methodology: An Evaluation'. The table doesn't consider movement within the time period considered.

${ }^{45}$ Source: Balance sheet summary (Data on Accumulated loan loss reserves and gross loans), Moody's credit analysis for IBRD, ADB, AfDB, EBRD. For IDB: Investor Presentation June 2012 Pg.15.

${ }^{46}$ Figure 1, IBRD Top Ten Borrowers Ranked By Share Of Total Loans Outstanding.

${ }^{47}$ Loan Approvals by Country (\%), 10 Largest Borrowers in 2011, Pg.13, Moody's credit analysis.

48 Table 5.4, Disbursements by Country, 2011, Annual report 2011.

${ }^{49}$ Pg. 9, Investor Presentation

http://www.eib.org/attachments/fi/2012-Q2-eib-investor-presentation.pdf

${ }^{50}$ Financial ratios, Performance Statistics (\%), Moody's Credit Analysis. 